\title{
The efficiency of bank branches
}

\section{Omid Takbiri, Mohammad Mohammadi* and Bahman Naderi}

Department of Industrial Engineering, Faculty of Engineering, Kharazmi University, Tehran, Iran

\begin{tabular}{l}
\hline C H R O N I C L E \\
\hline Article history: \\
Received March 5, 2015 \\
Received in revised format \\
August 162015 \\
Accepted September 312015 \\
Available online \\
October 9 2015 \\
\hline Keywords: \\
Banking industry \\
Efficiency \\
DEA
\end{tabular}

\section{A B S T R A C T}

Banking industry has significant contribution in development of economies of developing countries. Most banks execute their operations through different branches. Therefore it is important to measure the relative efficiencies of these branches. Data envelopment analysis (DEA) is one of the most useful tools in measuring banks' performance. The present paper aims to extract ranking pattern of banks based on performance evaluation using DEA analysis. In the present research, 120 bank branches of Bank Shahr in city of Tehran were selected and their efficiencies were evaluated using DEA technique. The results are discussed and compared with similar studies.

\section{Introduction}

An understanding of bank branch efficiency may help resolve different conceptual, measurement, and policy concerns about efficiency at the bank level (Yildirim, 2002; Berger et al., 2003). Measuring and assessment the operating efficiency of bank branches needs analytic techniques, which give insights beyond those available from accounting figures. Data Envelopment Analysis (DEA) (Charnes et al., 1978, 1985, 2013), a mathematical programming technique, gives insights in determining inefficient branches by explicitly investigating the mix of services provided and the resources implemented to have these bank services (Wang et al., 2014; Wanke \& Barros, 2014). Bank management determines the DEA results provide meaningful insights not available from other techniques, which concentrate on ways to contribute productivity (Sherman \& Gold, 1985; Zenios et al., 1997). Vassiloglou and Giokas (1990) presented an application of DEA for the Commercial Bank of Greece in evaluating the relative efficiency of bank branches. Oral and Yolalan (1990) performed an empirical investigation to compute the operating efficiencies of a set of 20 bank branches of a major Turkish Commercial Bank. The approach was based on the concepts and principles of DEA method. The results indicated that this type of method is not only complementary to traditionally implemented financial ratios but also a good

* Corresponding author. Tel \& Fax: +98 (21)88830891

E-mail address: mohammadi@khu.ac.ir (M. Mohammadi) 
bank management tool in reallocating resources between the branches to reach higher efficiencies. They also observed that the service-efficient bank branches were also the most profitable ones, implying the existence of a relationship between service efficiency and profitability.

Athanassopoulos (1997) focused on the evaluation of the productive efficiency of some Greek bank branches whose operations were characterised by the effort accomplished by management to pursue the banks' corporate aims. Drake and Hall (2003) utilized the non-parametric frontier approach, DEA, to analyze the technical and scale efficiency in Japanese banking using a recent cross-section sample. Efficiency analysis was performed across individual banks, bank types and bank size groups. Powerful size-efficiency relationships were built in terms of both technical and scale efficiency. They suggested that controlling for the exogenous effect of problem loans was essential in Japanese banking, especially for the smaller regional banks.

Mercan et al. (2003) presented a financial performance index for commercial banks, which helps us observe the impacts of scale and of the mode of ownership on bank behavior. It gives insight about the effects of financial liberalization, cross-country movements, and the effect of financial crises originating in neighboring countries e.g. Russia. The study used DEA to selected fundamental financial ratios based on the data over the period 1989-99 data from commercial banks in Turkey. Year-by-year results described the impacts on this sector of major shifts in both national macro-economic policy and different international developments.

Stewart et al. (2016) investigated bank efficiency in Vietnam from 1999 to 2009. They applied a unique data sample, which helps us capture the development of the Vietnamese banking sector. The results showed that large and very large banks were more efficient than small and medium sized banks with small banks having the lowest efficiency scores in the system. Tsolas and Charles (2015) included risk into bank efficiency and to find a snapshot of the efficiency profile of the Greek banking industry. Efficiency was measured by means of DEA model in which the financial risk was proxied by credit risk provisions. Stoica et al. (2015) implemented DEA to measure the aggregate efficiency score for each of the 24 banks and utilized PCA to classify the banks into various operational strategies groups based on their relative efficiency scores. The results indicated that there were very few banks utilized Internet banking services in their production process to increase their level of efficiency. Azarbad et al. (2015) used DEA technique to determine the most efficient places for establishing bank branches for one of the biggest Iranian Bank named Pasargad. Zarinkamar and Alam-Tabriz (2014) presented a study to measure the relative efficiency of 30 branches of an Iranian bank named Bank Mellat. The study considered four inputs including operating expenses, interest paid, capital expenditures and fixed assets. They also applied customers' bank deposit, commissions and loans paid as output parameters. Using three DEA methods, the study measured the relative efficiencies of all units. They reported that most banks were working under desirable level of efficiency.

\section{The proposed study}

The proposed study of this paper uses the data gathered from Bank Shahr. Bank Shahr is a new bank established in 2009 by the municipalities of Tehran and other major cities of Iran. Supported by capital of IRR 1600 billion Rials, the firm was initially authorized by the Central Bank of Iran (CBI) to operate as a Financial and Credit Institution. Bank Shahr was awarded a full banking permit by the CBI in 2010. The primary objective of this bank is to provide modern, efficient banking services to private individuals and businesses, and to deliver necessary funding for development and infrastructure projects. Bank Shahr has an impressive track-record of supporting various municipalities across Iran, providing liquidity for a diverse range of projects.

The present paper aims to extract ranking pattern of this bank based on performance evaluation using DEA analysis and the ranking of efficient units. In the present research, 120 bank branches in city of Tehran were selected and their efficiencies were evaluated using DEA technique. In order to select the 
most appropriate input/output factors, the study designs a questionnaire and distributes it among some experts.

Cronbach alpha has been calculated within desirable level. In our survey, all questions were designed in Likert scale between one and five. Table 1 demonstrates some basic statistics about different factors. We have also selected the most important factors for DEA implementation. According to Table 1 some indexes such as work quality, service training, motivation of employees, number of customers, branches' capital, capital adequacy ratio, average queue time customer expectations, ROI, profit margins are statistically significant.

In our survey, quality of work, in-service training, staff motivation, total client assets branches are considered as input and capital adequacy ratio, the average customer waiting time in the queue, investment, profit margins are considered as the output

\section{Table 1}

Questionnaire sample

\begin{tabular}{lrrr}
\hline Step/step aspects & mean & Test value & Significance test \\
\hline Capital adequacy ratio & 4.98 & 3 & 0.000 \\
Return on equity & 2.01 & 3 & $>0.05$ \\
Returns & 3.67 & 3 & 0.000 \\
\hline Profit margin & 3.67 & 3 & 0.000 \\
Asset return & 3.67 & 3 & $>0.05$ \\
\hline Staff number & 2.67 & 3 & $>0.05$ \\
The average time a customer wait in the queue & 4.05 & 3 & 0.000 \\
Ability to attract investors & 4 & 3 & 0.000 \\
Area & 1.08 & 3 & $>0.05$ \\
The average number of customers per day & 4.2 & 3 & 0.000 \\
Cost & 2.99 & 3 & 0.000 \\
Capital & 3.98 & 3 & 0.000 \\
Equipment & 2.9 & 3 & $>0.05$ \\
\hline Income & 1.8 & 3 & $>0.05$ \\
Saving & 3 & 3 & $>0.05$ \\
\hline Facilities & 2.7 & 3 & $>0.05$ \\
Quality & 3.7 & 3 & 0.000 \\
On the job trainings & 4.8 & 3 & 0.000 \\
\hline Staff motivations & 3.09 & 3 & 0.000 \\
\hline
\end{tabular}

\section{Results, discussion and conclusion}

The proposed study of this paper uses two methods of constant to return (CCR) (Charnes et al., 1978) and variable return to scale (BCC) (Charnes et al., 1984) for measuring the relative efficiencies of various banks. Table 2 shows the results of our survey. As expected BCC model represents relatively higher numbers compared with CCR model. In other words, BCC model represents more optimistic figures about the relative efficiencies of various banks. In the present research, 120 bank branches in city of Tehran were selected and their efficiencies were evaluated using DEA technique. According to the results of the CCR, 50 out of 120 branches were efficient. This means that $58 \%$ of the bank branches were inefficient and it is possible to make some changes on inputs and outputs of the inefficient branches to improve the relative efficiencies of inefficient units. The results of this survey are consistent with other results. Zarinkamar and Alam-Tabriz (2014), for instance, measured the relative efficiency of other banks and reported that most banks were inefficient. Soltanifar and Farhadi (2014) and Ghotbuee et al. (2012) presented an output oriented DEA to measure the relative efficiency of some Iranian private banks in Iran and reported that most banks were efficient. 
Table 2

Results of CCR and BCC models and rankings

\begin{tabular}{|c|c|c|c|c|c|c|c|c|c|}
\hline DMU & CCR & BCC & Scale & RANK & DMU & CCR & BCC & Scale & RANK \\
\hline 1 & 0.96 & 1 & 0.96 & 64 & 61 & 1 & 1 & 1 & 42 \\
\hline 2 & 0.85 & 0.87 & 0.97 & 92 & 62 & 1 & 1 & 1 & 18 \\
\hline 3 & 1 & 1 & 1 & 2 & 63 & 1 & 1 & 1 & 55 \\
\hline 4 & 0.95 & 1 & 0.95 & 66 & 64 & 0.98 & 1 & 0.98 & 60 \\
\hline 5 & 0.98 & 0.98 & 0.999 & 90 & 65 & 0.84 & 1 & 0.84 & 85 \\
\hline 6 & 1 & 1 & 1 & 3 & 66 & 1 & 1 & 1 & 16 \\
\hline 7 & 0.96 & 1 & 0.96 & 75 & 67 & 1 & 1 & 1 & 1 \\
\hline 8 & 0.97 & 1 & 0.97 & 62 & 68 & 0.90 & 1 & 0.90 & 84 \\
\hline 9 & 0.94 & 0.94 & 0.998 & 63 & 69 & 0.92 & 1 & 0.92 & 71 \\
\hline 10 & 1 & 1 & 1 & 4 & 70 & 1 & 1 & 1 & 17 \\
\hline 11 & 0.82 & 0.90 & 0.91 & 116 & 71 & 0.85 & 0.89 & 0.95 & 111 \\
\hline 12 & 1 & 1 & 1 & 5 & 72 & 0.88 & 0.89 & 0.99 & 91 \\
\hline 13 & 1 & 1 & 1 & 6 & 73 & 0.80 & 0.81 & 1.00 & 118 \\
\hline 14 & 1 & 1 & 1 & 7 & 74 & 0.99 & 1 & 0.99 & 59 \\
\hline 15 & 0.88 & 1 & 0.88 & 79 & 75 & 1 & 1 & 1 & 61 \\
\hline 16 & 1 & 1 & 1 & 56 & 76 & 1 & 1 & 1 & 15 \\
\hline 17 & 0.92 & 1 & 0.92 & 73 & 77 & 1 & 1 & 1 & 41 \\
\hline 18 & 1 & 1 & 1 & 8 & 78 & 0.87 & 0.87 & 0.999 & 93 \\
\hline 19 & 0.99 & 1 & 0.99 & 70 & 79 & 0.95 & 1 & 0.95 & 67 \\
\hline 20 & 1 & 1 & 1 & 9 & 80 & 0.75 & 0.75 & 0.999 & 120 \\
\hline 21 & 1 & 1 & 1 & 43 & 81 & 0.84 & 0.84 & 0.996 & 94 \\
\hline 22 & 1 & 1 & 1 & 53 & 82 & 0.75 & 0.84 & 0.89 & 110 \\
\hline 23 & 1 & 1 & 1 & 44 & 83 & 0.86 & 0.89 & 0.97 & 95 \\
\hline 24 & 1 & 1 & 1 & 11 & 84 & 0.83 & 0.93 & 0.89 & 96 \\
\hline 25 & 1 & 1 & 1 & 54 & 85 & 1 & 1 & 1 & 40 \\
\hline 26 & 0.74 & 0.75 & 0.99 & 106 & 86 & 0.77 & 0.78 & 0.999 & 112 \\
\hline 27 & 0.93 & 0.98 & 0.95 & 89 & 87 & 0.85 & 0.86 & 0.98 & 97 \\
\hline 28 & 1 & 1 & 1 & 45 & 88 & 0.91 & 1 & 0.91 & 78 \\
\hline 29 & 0.72 & 0.73 & 0.98 & 107 & 89 & 0.69 & 0.77 & 0.90 & 113 \\
\hline 30 & 1 & 1 & 1 & 10 & 90 & 1 & 1 & 1 & 13 \\
\hline 31 & 0.81 & 1 & 0.81 & 105 & 91 & 0.83 & 1 & 0.83 & 83 \\
\hline 32 & 1 & 1 & 1 & 12 & 92 & 0.86 & 1 & 0.86 & 82 \\
\hline 33 & 0.81 & 0.83 & 0.97 & 104 & 93 & 0.94 & 0.94 & 1 & 86 \\
\hline 34 & 1 & 1 & 1 & 46 & 94 & 1 & 1 & 1 & 14 \\
\hline 35 & 0.68 & 0.70 & 0.98 & 115 & 95 & 0.70 & 0.75 & 0.93 & 109 \\
\hline 36 & 0.90 & 1 & 0.90 & 77 & 96 & 0.83 & 0.84 & 0.98 & 98 \\
\hline 37 & 0.94 & 0.94 & 1.00 & 88 & 97 & 0.91 & 0.95 & 0.97 & 87 \\
\hline 38 & 0.85 & 0.85 & 1 & 102 & 98 & 1 & 1 & 1 & 36 \\
\hline 39 & 0.95 & 1 & 0.95 & 67 & 99 & 0.87 & 1 & 0.87 & 80 \\
\hline 40 & 0.82 & 0.83 & 0.98 & 103 & 100 & 1 & 1 & 1 & 19 \\
\hline 41 & 1 & 1 & 1 & 22 & 101 & 0.78 & 0.78 & 0.99 & 108 \\
\hline 42 & 1 & 1 & 1 & 21 & 102 & 1 & 1 & 1 & 37 \\
\hline 43 & 1 & 1 & 1 & 47 & 103 & 0.91 & 1 & 0.91 & 76 \\
\hline 44 & 0.93 & 1 & 0.93 & 72 & 104 & 0.93 & 1 & 0.93 & 74 \\
\hline 45 & 1 & 1 & 1 & 20 & 105 & 1 & 1 & 1 & 38 \\
\hline 46 & 1 & 1 & 1 & 49 & 106 & 1 & 1 & 1 & 39 \\
\hline 47 & 1 & 1 & 1 & 51 & 107 & 0.97 & 1 & 0.97 & 61 \\
\hline 48 & 1 & 1 & 1 & 48 & 108 & 0.88 & 0.96 & 0.92 & 99 \\
\hline 49 & 0.69 & 0.75 & 0.92 & 114 & 109 & 1 & 1 & 1 & 58 \\
\hline 50 & 1 & 1 & 1 & 23 & 110 & 1 & 1 & 1 & 28 \\
\hline 51 & 0.88 & 1 & 0.88 & 81 & 111 & 1 & 1 & 1 & 29 \\
\hline 52 & 0.95 & 1 & 0.95 & 68 & 112 & 1 & 1 & 1 & 57 \\
\hline 53 & 1 & 1 & 1 & 24 & 113 & 1 & 1 & 1 & 32 \\
\hline 54 & 1 & 1 & 1 & 27 & 114 & 1 & 1 & 1 & 52 \\
\hline 55 & 0.85 & 0.91 & 0.94 & 101 & 115 & 1 & 1 & 1 & 34 \\
\hline 56 & 0.94 & 1 & 0.94 & 69 & 116 & 0.96 & 1 & 0.96 & 65 \\
\hline 57 & 0.96 & 0.99 & 0.97 & 100 & 117 & 1 & 1 & 1 & 30 \\
\hline 58 & 1 & 1 & 1 & 25 & 118 & 1 & 1 & 1 & 50 \\
\hline 59 & 1 & 1 & 1 & 33 & 119 & 1 & 1 & 1 & 35 \\
\hline 60 & 1 & 1 & 1 & 26 & 120 & 1 & 1 & 1 & 31 \\
\hline
\end{tabular}




\section{Acknowledgement}

The authors would like to thank the anonymous referees for constructive comments on earlier version of this paper. We would like to also acknowledge the cooperation of management team of Bank Shahr for accomplishment of this survey.

\section{References}

Athanassopoulos, A. D. (1997). Service quality and operating efficiency synergies for management control in the provision of financial services: Evidence from Greek bank branches. European Journal of Operational Research, 98(2), 300-313.

Azarbad, M., Soltani, A \& Shojaie, A. (2015). An empirical DEA investigation for development of new bank’s branches. Management Science Letters, 5(4), 331-336.

Berger, A. N., Leusner, J. H., \& Mingo, J. J. (1997). The efficiency of bank branches. Journal of Monetary Economics, 40(1), 141-162.

Charnes, A., Cooper, W. W., \& Rhodes, E. (1978). Measuring the efficiency of decision making units. European journal of operational research, 2(6), 429-444.

Charnes, A., Cooper, W. W., Golany, B., Seiford, L., \& Stutz, J. (1985). Foundations of data envelopment analysis for Pareto-Koopmans efficient empirical production functions. Journal of econometrics, 30(1), 91-107.

Charnes, A., Cooper, W. W., Lewin, A. Y., \& Seiford, L. M. (Eds.). (2013). Data envelopment analysis: Theory, methodology, and applications. Springer Science \& Business Media.

Drake, L., \& Hall, M. J. (2003). Efficiency in Japanese banking: An empirical analysis. Journal of Banking \& Finance, 27(5), 891-917.

Ghotbuee, A., Hemati, M \& Fateminezhad, R. (2012). An empirical study based on BSC-DEA to measure the relative efficiencies of different health care centers in province of Semnan, Iran. Management Science Letters, 2(7), 2643-2650.

Mercan, M., Reisman, A., Yolalan, R., \& Emel, A. B. (2003). The effect of scale and mode of ownership on the financial performance of the Turkish banking sector: results of a DEA-based analysis. Socio-Economic Planning Sciences, 37(3), 185-202.

Oral, M., \& Yolalan, R. (1990). An empirical study on measuring operating efficiency and profitability of bank branches. European Journal of Operational Research, 46(3), 282-294.

Sherman, H. D., \& Gold, F. (1985). Bank branch operating efficiency: Evaluation with data envelopment analysis. Journal of Banking \& Finance, 9(2), 297-315.

Soltanifar, M \& Farhadi, F. (2014). An application of data envelopment analysis for measuring the relative efficiency in banking industry. Management Science Letters, 4(5), 1021-1026.

Stewart, C., Matousek, R., \& Nguyen, T. N. (2016). Efficiency in the Vietnamese banking system: A DEA double bootstrap approach. Research in International Business and Finance, 36, 96-111.

Stoica, O., Mehdian, S., \& Sargu, A. (2015). The impact of internet banking on the performance of Romanian banks: DEA and PCA approach. Procedia Economics and Finance, 20, 610-622.

Tsolas, I. E., \& Charles, V. (2015). Incorporating risk into bank efficiency: A satisficing DEA approach to assess the Greek banking crisis. Expert Systems with Applications, 42(7), 3491-3500.

Vassiloglou, M., \& Giokas, D. (1990). A study of the relative efficiency of bank branches: an application of data envelopment analysis. Journal of the Operational Research Society, 41(7), 591597.

Wang, K., Huang, W., Wu, J., \& Liu, Y. N. (2014). Efficiency measures of the Chinese commercial banking system using an additive two-stage DEA. Omega, 44, 5-20.

Wanke, P., \& Barros, C. (2014). Two-stage DEA: An application to major Brazilian banks. Expert Systems with Applications, 41(5), 2337-2344.

Yildirim, C. (2002). Evolution of banking efficiency within an unstable macroeconomic environment: the case of Turkish commercial banks. Applied Economics, 34(18), 2289-2301. 
1116

Zarinkamar, R \& Alam-Tabriz, A. (2014). Bank branch operating efficiency: evaluation with data envelopment analysis. Management Science Letters, 4(10), 2307-2312.

Zenios, C. V., Zenios, S. A., Agathocleous, K., \& Soteriou, A. C. (1999). Benchmarks of the efficiency of bank branches. Interfaces, 29(3), 37-51. 